\title{
ONE OR MANY NORMATIVITIES?
}

\author{
Normativity pervades our lives \\ O. O’Neill
}

\begin{abstract}
The aim of the present investigation is to sketch a new approach to analysing normativity. First (\$1-2) I locate the problem of normativity in the landscape of contemporary philosophy and focus on the dispute between naturalism and antinaturalism. Then (§3) I discuss the so-called top-down approach to studying normativity, to which I oppose the bottom-up approach inspired by contemporary philosophy of science (\$4). I see the integration of these approaches as enabling investigations of normative phenomena that do not reduce them to just one type of normativity (e.g. morality).
\end{abstract}

Keywords: normativity, naturalism, antinaturalism, normative field, philosophy of science

1. The normative question. 2. Understanding normativity and the dispute over naturalisation. 3. The top-down approach to studying normativity. 4. The bottom-up approach to studying normativity.

\section{THE NORMATIVE QUESTION}

In her now classic book The Sources of Normativity Christine Korsgaard claims that, when we look for philosophical foundations of morality we are less interested in explaining certain types of practices than in answering the question of what justifies the claim that morality has a certain impact on people. She calls this the normative question. The question comprises three aspects: (1) What do moral concepts mean?; (2) How can they be used?; and (3) Where do they come 
from? ? $^{1}$ According to Korsgaard, these three questions lead to a theory of moral concepts which is also a theory of normativity.

This claim raises certain doubts, however. It is enough to scan the publications devoted to normativity or take a quick overview of the bibliographic resources containing "normativity" as a keyword, to conclude that it is not possible to use it in just one sense. Researchers write about the normativity of meaning, perception and beliefs. We can also read about normative requirements, processes and functions. Seen through the prism of current disputes over normativity, the normativity question posed by Korsgaard is not restricted to moral concepts as normative concepts are not exclusively moral. Rather, morality is only a narrow class of normativity. The object of the normative question is, instead, normativity par excellence.

Korsgaard's suggestion to think about normativity in terms of moral concepts, albeit limited, exposes or perhaps expresses a certain general attitude or belief about what normativity is and who investigates it. In this approach, normativity is a problem studied by ethicists and is mainly concerned with such issues as the applicability of principles or rules, obligations or duties, the naturalistic fallacy, the problem of ethical naturalism, etc. Those sceptical of purely philosophical problems would include lawyers, sociologists and possibly psychologists as competent investigators of normativity. Such attitudes originate in the very history of philosophy.

Even though the problem of normativity has been present in philosophy from its very beginning, it is only in modern philosophy that it has been expressed, to some extent, as a problem related primarily to ethics and law and then to methodology, logic and epistemology. ${ }^{2}$ Today, it is the focus of the philosophy of language,

1 C. Korsgaard, The Sources of Normativity, Cambridge University Press, New York 1996, 10-11.

2 See Ibidem; P. Duchliński, Normatywność - jej źródła i sposoby badania. Analiza metateoretyczna, in: O normatywności w etyce, eds. P. Duchliński, A. Kobyliński, R. Moń, E. Podrez, Wydawnictwo Wam, Kraków 2015, 16-62; B. Brożek, Pojęcie normatywności, 
philosophy of mind and philosophy of biology. It is also relevant for cognitive scientists, psychologists and sociologists. Importantly, scholars are slowly moving away from a conception of normativity framed in ethical and legal categories. To describe normativity as a separate and individual issue, we need to understand that the ethical perspective is not a privileged way of approaching it.

\section{UNDERSTANDING NORMATIVITY AND THE DISPUTE OVER NATURALISATION}

A review of the existing literature on normativity shows that there is no clear consensus about its definition. On the one hand, it seems that the dispute over normativity is ontological to the extent that it concerns the type of beings or objects constituting norms, values or duties. On the other hand, the current debate on this issue might give the impression that it is a meta-dispute relating to the concepts employed, the ways of justifying norms and the problem of their potential naturalisation. Disregarding the views of their opponents, different authors suggest different definitions of normativity on grounds which sometimes seem arbitrary.

In the literature we can find the following applications of, or reference areas related to, the concept of "normativity":"

1. Normativity is a subjective ability to create norms, rules and principles defining human practice. What is meant here are the so-called normative competences; ${ }^{4}$

in: Fenomen normatywności, eds. A. Brożek, B. Brożek, J. Stelmach, Copernicus Center Press, Kraków 2013, 19-44.

3 I refer in particular to the analysis in P. Duchliński, Normatywność - jej źródła i sposoby badania, op. cit., 28-33; D. Henderson, Norms, in: The Oxford Handbook of Philosophy of Social Science, ed. H. Kingcaid, Oxford University Press, Oxford 2017, 409-435;

C. Bicchieri, The Grammar of Society, Cambridge University Press, New York 2006.

4 See A. Waleszczyński, Knobe Effect from the Perspective of the Thomist Ethics. The Problem of Normative Systems and Competences, in present volume, 65-92. 
2. Normativity amounts to certain ethical standards, i.e. judgements about what should and should not be; ${ }^{5}$

3. Normativity is a property of statements or linguistic expressions such as statements of obligations, imperatives, questions, declarative statements, norms, etc.; ${ }^{6}$

4. Normativity is closely related to rules of action understood as objective reasons for action and different from motives or impulses;

5. Normativity as a property of reality, some objects, states of affairs and events; ${ }^{8}$

6. Normativity is a property of so-called ethical and legal normative systems, i.e. laws, codes, etc. They should be understood as specific sets of practical and theoretical statements linked by logical and non-logical relations; ${ }^{9}$

7. Normativity is an epistemic property of concepts justifying statements, judgements, etc. Concepts such as rationality, reasoning and reasons are taken to be normative concepts; ${ }^{10}$

5 See Ch. Korsgaard, The Sources of Normativity, op. cit., 22.

6 See P. Boghossian, The Rule-Following Considerations, Mind 98(1989), 507-549; P. Boghossian, The Normativity of Content, Philosophical Issues 13(2003), 31-45; S. Kripke, Wittgenstein on Rules and Private Language, Harvard University Press, Cambridge MA 1982; D. Whiting, What is the Normativity of Meaning?, Inquiry 59(2013)3, 219-238.

7 See B. Brożek, Pojęcie normatywności, op. cit.; D. Henderson, Norms, op. cit., 410; M. Piekarski, Od typiki doświadczenia do normatywnej antycypacji. Przyczynek do fenomenologii normatywności, Filo-Sofija 33(2016)2, 71-86; M. Piekarski, Two Arguments Supporting the Thesis of the Predictive Nature of Reasons for Action, included in the present volume, 93-119.

8 See N. Hartmann, Ethik, De Gruyter, Berlin 1926; R. Ingarden, Wykłady z etyki, PWN, Warszawa 1989; R. Moń, Warto czy należy? Studium na temat istoty i źródeł normatywności, Wydawnictwo Naukowe UKSW, Warszawa 2011; Scheler M., Der Formalismus in der Ethik und die materiale Wertethik: Neuer Versuch der Grundlegung eines ethischen Personalismus, Felix Meiner Verlag, Hamburg 2014.

9 See J. Kalinowski, Teoria poznania praktycznego, WN KUL, Lublin 1960; H. Kelsen, General Theory of Law and State, Harvard University Press, Cambridge MA 1945.

10 See R.B. Brandom, Making It Explicit: Reasoning, Representing, and Discursive Commitment, Harvard University Press, Cambridge 1994; R.B. Brandom, Articulating Reasons, 
8. Normativity as a property of social interactions. What is normative in this context are the ways in which an individual is expected to behave in a given social group, some behavioural patterns and the rules governing actions; ${ }^{11}$

9. Normativity as a psychological property shared by a given population: a learned form of behaviour defined by certain individual circumstances. ${ }^{12}$

While this overview does not exhaust the multitude of references to normativity in contemporary philosophy, ${ }^{13}$ it does expose certain tendencies. It seems that these different ways of understanding or perceiving normativity stem from more fundamental investigations, which should be linked to the discussion between proponents and opponents of naturalism. The naturalism - anti-naturalism opposition is not new in philosophy, but it gains a new meaning in the context of the dispute about normativity.

Harvard University Press, Cambridge MA 2000; J. Broome., Is rationality normative?, Disputatio 23(2007), 161-178.

11 See C. Bicchieri, R. Muldoon, Social Norms, in: The Stanford Encyclopedia of Philosophy (Spring 2014 Edition), ed. E.N. Zalta, URL = https://plato.stanford.edu/archives/spr2014/ entries/social-norms/ (access 02.01.2018); D. Henderson, Norms, op. cit., 409; W. Wachowski, Normatywność usytuowana. Ujęcie ekologiczne, included in the present volume, 143-165.

12 L. Darden, Reasoning in Biological Discoveries, Cambridge University Press, Cambridge MA 2006.

13 Ingarden suggests an interesting typology of uses of the concept of a ,norm" which, I believe, may be applied to contemporary reflections on normativity. He differentiates between (1) objective meaning (existing pattern, template; normal as opposed to abnormal; etc.); (2) meaning as a state of affairs (what should happen; what is to be done; a prescribed desired state of affairs, e.g. the weight of coins in a given country); (3) logical meaning (judgment about a desired state of affairs; reflection establishing the way something should be; order for something to be such and such); (4) linguistic meaning (statement expressing certain norms); (5) cognitive meaning (cognitive criterion, e.g. truth). R. Ingarden, Wykłady z etyki, op. cit., 17, 143-144. Bicchieri suggests we should differentiate between three types of norms: social norms, descriptive norms and conventions. C. Bicchieri, The Grammar of Society, op. cit. 
In this dispute, naturalism has two aspects. The first, which might be called evolutionary naturalism, is summed up in the following statements:

1. in a way, normativity may be equated with morality; ${ }^{14}$

2. morality is a superstructure built on social skills developed during biological evolution. Importantly, such skills are common among other primates as well; $;^{15}$

3. the chief aim of morality is to settle conflicts in a group. Thus understood, morality is first and foremost a kind of social mechanism;

4. morality is not an expression of rationality but is primarily in affects and experienced emotions;

5. normative systems are an effect of cultural evolution.

In the dispute over normativity, evolutionary naturalism may be opposed to biological naturalism. ${ }^{16}$ This form of naturalism rests upon several fundamental assumptions (occurring jointly or separately):

1. normativity is strictly related to biological functions that are either evolutionary or informational ${ }^{17}$

14 P. S. Churchland, Braintrust, Princeton University Press, Princeton 2011; D. Copp, Moral naturalism and Three Grades of Normativity, in: Normativity and Naturalism, ed. P. Schaber, Ontos Verlag, Frankfurt am Main 2004, 7-45; P.S. Davies, Norms of Nature. Naturalism and the Nature of Functions, MIT Press, Cambridge MA 2001; F. de Waal, Primates and Philosophers: How Morality Evolved, Princeton University Press, New Jersey 2006.

15 F. de Waal, Primates and Philosophers, op. cit.; F. de Waal, Natural Normativity: The 'Is' and 'Ought' of Animal Behavior. Behaviour 151(2014), 185-204; J. Haidt, The Emotional Dog and Its Rational Tail, Psychological Review 108(2001)4, 814-834; M. Tomasello, A Natural History of Human Thinking, Harvard University Press, Cambridge MA 2014.

16 Evolutionary naturalism and biological naturalism interpenetrate. A good example of this "interpenetration” is Ruth Millikan's teleosemantics, which explains biological functions as products of natural selection (R.G. Millikan, Language, thought, and other biological categories: new foundations for realism, The MIT Press, Cambridge MA 1984; R.G. Millikan, Biofunctions, in: Functions. New Essays in the Philosophy of Psychology and Biology, eds. A. Ariew, R. Cummins, M. Perlaman, Oxford University Press, Oxford 2002.) I draw a distinction between the two positions depending on whether they put greater emphasis on evolutionary mechanisms or biological structures.

17 R. G. Millikan, Biofunctions, op. cit.; F. Dretske, Explaining Behavior: Reasons in a World of Causes. MIT Press, Cambridge MA 1988. See also P. Godfrey-Smith, A Modern History 
2. stability in a given living organism is ensured by certain functions sustaining its balance. Such functions are normative for a given stability. Normativity as such is emergent in relation to the property of stability. In this respect, representations can also be normative if they are emergent in relation to different biological properties. Crucially, conditioning is dynamic and causal rather than evolutionary; ${ }^{18}$

3. the processes of homeostasis are themselves normative, based as they are on the principle of minimising the so-called free energy, ${ }^{19}$

4. in its fundamental aspect, normativity relates to the simplest behaviours of non-complex organisms (e.g. bacteria). It is important to consider this in light of the insights provided by robotics based on dynamic models developed since the 1990s. ${ }^{20}$

Common to both evolutionary and biological naturalism is the belief that we can obtain crucial information about morality and normativity by studying the operation and structure of the brain. The answer to the question of normativity lies in neuronal mechanisms and, more specifically, in the explanations of their functions. This does not mean that by explaining how the brain works we will

Theory of Functions, Noûs 28(1994), 344-362.

18 M. Bickhard, Process and Emergence: Normative Function and Representation, in: Process Theories. Crossdisciplinary studies in dynamic categories, ed. J. Seibt, Springer, Dordrecht 2003, 121-155. DOI: 10.1007/978-94-007-1044-3_6; M. Bickhard, The interactivist model, Synthese 3(2009)166, 547-591. DOI: 10.1007/s11229-008-9375-x; M. Bickhard, W. Christensen, The Process Dynamics of Normative Function, The Monist 85(2002)1, 3-28.

19 K.J. Friston, Free Energy Principle for Biological Systems, Entropy 14(2012), 2100-2121; K.J. Friston, K.E. Stephan, Free-energy and the brain, Synthese 159(2007), 417-458.

20 X. Barandiaran, M. Egbert, Quantifying Normative Behaviour and Precariousness in Adaptive Agency, in: Proceedings of the 11th European Conference on Artificial Life, eds. T. Lenaerts, M. Giacobini et al., Presented at the ECAL, MIT Press 2011, 210-218; X. Barandiaran, M. Egbert, Norm-Establishing and Norm-Following in Autonomous Agency, Artificial Life Journal 20(2014), 5-28; X. Barandiaran, E. Di Paolo, M. Rohde, Defining Agency. individuality, normativity, asymmetry and spatio-temporality in action, Journal of Adaptive Behavior 17(2009)5, 367-386, DOI: 10.1177/1059712309343819. 
clarify all normative problems and concepts. Rather, it means is that an approach based on such explanations will help us provide an answer to the question of the sources of normativity that will refer neither to supernatural properties or beings nor to concepts of rationality or obligation ${ }^{21}$.

As a group, proponents of anti-naturalism are as heterogeneous as their naturalist opponents. However, they share two basic beliefs that may be formulated and emphasised in different ways:

1. Normative statements cannot be fully explained by descriptive concepts taken from the language of natural sciences; ${ }^{22}$

2. Normative properties cannot be reduced to natural properties. ${ }^{23}$

The minimalism that is often stressed as typical of contemporary philosophy is manifested in various non-foundationalist approaches to the study of normativity. ${ }^{24}$ The strategy of such approaches is that „you do not start from axioms, but from hypotheses that may be confirmed or undermined by examination". ${ }^{25}$ They are popular in

21 In this context, it is worth quoting Patricia Churchland: "On my hypothesis regarding the neural basis of moral behavior, morality is as real as can be - it is as real as social behavior. Actual human moral behavior, in all its glory and complexity, should not be cheapened by the false dilemma: either God secures the moral law or morality is an illusion. It is a false dilemma because morality can be - and I argue, is - grounded in our biology, in our capacity for compassion and our ability to learn and figure things out" (P.S. Churchland, Braintrust, op. cit., 200).

22 According to Robert Audi, negating this belief is of key importance for contemporary naturalism. R. Audi, Natura normatywności oraz projekt naturalizacji pojęć normatywnych, in: W świecie powinności, eds. B. Brożek, M. Hohol, Ł. Kurek, J. Stelmach, Copernicus Center Press, Kraków 2013, 38.

23 R. Audi, Ethical Naturalism, in: The Oxford Handbook of Ethical Theory, ed. D. Copp, Oxford University Press, Oxford 2006, 92. Among its other facets, naturalism may be reductionist when it claims that normative properties may be reduced to natural properties, and non-reductionist when it maintains, for example, that normative properties supervene on natural ones.

24 M. Heller, Przeciw fundacjonizmowi, in: Filozofia i wszechświat, Universitas, Kraków 2006, 82-104.

25 P. Duchliński, Normatywność, op. cit., 20. 
naturalistic circles, but are also endorsed by many researchers working in the anti-naturalistic tradition.

\section{THE TOP-DOWN APPROACH TO STUDYING NORMATIVITY}

The conclusion to draw from the analysis above is that there is a tendency in philosophy to make the answer to the normative question dependent on favouring one of the views involved in the dispute over naturalism. Such an approach is reasonable, as each time we ask a question we take a certain theoretical position that defines us in terms of methodology and worldview. I will call this the top-down approach. It is based on the belief that normativity is an object of study just like any other topic investigated by philosophers (e.g. judgments, desires, concepts, values and rules). Hence, we should establish certain pre-assumptions concerning methodology, language and research tools. With all its validity and effectiveness, the top-down approach forces researchers to restrict what I will refer to as a normative field to one of its regions.

What is a normative field? To explain this concept, it is best to imagine that normativity resembles an ocean. This analogy illustrates the idea that normativity is very varied, indeterminate and diversified by emerging specifications, just like we have different islands, archipelagos and continents in an ocean. Moral normativity involved in ethical investigations is one such island. But there are also other regions such as the normativity of law, mathematics, logic, etc. In addition to such large islands or continents, we can identify regions related to the normativity of empirical theories and laws, the normativity of artistic creations, or even the specific area of normativity governing the design of interactions and artefacts. ${ }^{26}$ Thus, a normative field encompasses many domains and problems.

26 See M. Piekarski, W. Wachowski, Artifacts as Social Things: Design-Based Approach to Normativity, under review. 
To study it, researchers must divide their labour and maintain a methodological discipline. ${ }^{27}$ In a way, therefore, the top-down method reduces the normative field to one of its regions.

The above analysis shows that the explanation of the sources or nature of normativity is closely related to the explanation of the sources or nature of morality. More specifically, by adopting one of the beliefs in the dispute over naturalism as our point of departure, we have already made concrete decisions about what normativity is. I will illustrate this with two examples:

1. Naturalistic position: according to evolutionary naturalism, all normativity can be traced back to evolutionarily acquired social mechanisms. ${ }^{28}$ In line with this view, normativity is tantamount to morality. How, then, can we explain, for example, the normative nature of mathematical equations or logical statements without succumbing to the once popular psychologism? ${ }^{29}$ Current studies into the mechanisms of mathematical cognition offer their phylo- and ontogenetic explanations. ${ }^{30}$ They do not, however, state clearly whether

27 The metaphor of the normative field is not to be taken too literally. It is a useful fiction expressing the belief that normativity is not uniform but contains many minor themes, issues and problem regions referred to as normative. Lying behind this metaphor, however, there is a specific metaphysical question I cannot address here: is normativity just an umbrella term for different types of constructs described as normative? Or is there a normativity par excellence manifesting itself in different ways (e.g. in ethics, law, rules of action or art)?

28 De Waal claims that "Natural selection has the capacity of producing an incredible range of organisms, from the most asocial and competitive to the kindest and gentlest. The same process may not have specified our moral rules and values, but it has provided us with the psychological makeup, tendencies, and abilities to develop a compass for life's choices that takes the interests of the entire community into account, which is the essence of human morality" (F. de Waal, Primates and Philosophers, op. cit., 58).

29 See M. Piekarski, Frans de Waal i filozofowie, Avant. Trends in Interdisciplinary Studies 3(2015)VI, 138-147.

30 M. Hohol, The Normativity of Mathematics. A Neurocognitive Approach, in: The Many Faces of Normativity, eds. J. Stelmach, B. Brożek, M. Hohol, Copernicus Center Press, 
the normativity of mathematical objects can be explained by reference to such mechanisms;

2. Anti-naturalistic position: proponents of anti-naturalism underline that normative concepts cannot be fully naturalised without committing the naturalistic fallacy. In his Principia Ethica, Moore said that fundamental normative concepts (which he understood as ethical concepts) cannot be defined in non-normative (descriptive) terms. Although this view has been criticised on different grounds, Moore's anti-naturalistic realism still has its ardent supporters. Without getting into the details of the discussion over Moore's view, it is worth considering its consequences for the problem of normativity. Like in (1), here too normativity is equated with morality. In a way, the anti-naturalistic perspective favours treating normativity as irreducible to, for example, social mechanisms. But is it necessary to explain, for instance, the normative nature of the rules for using a device or savoir vivre principles by reference to ideal or supernatural normative entities? It seems not.

\section{THE BOTTOM-UP APPROACH TO STUDYING NORMATIVITY}

I suggest opposing the top-down approach with the bottom-up approach. I understand the latter as an approach to the study of normativity that describes the ways in which normativity is manifested in human activity. This approach has been inspired by contemporary philosophy of science, which does not so much analyse specific concepts or develop new accounts as focus on the analysis of knowledge-generating practices. ${ }^{31}$ For example, when answering the question

Kraków 2012, 191-222.

31 See C.F. Craver, When mechanistic models explain, Synthese 153(2006)3, 355-376, DOI: 10.1007/s11229-006-9097-x; E. Hutchins, Cognition in the wild, MIT Press, Cambridge MA 1995; E. Hutchins, Cognitive Ecology, Topics in Cognitive Science 2(2010)4, 705-715; P.K. Machamer, L. Darden, C.F. Craver, Thinking about Mechanisms, Philosophy 
"what is the mind?" the supporters of this approach do not focus on what such and such thinkers have said about the mind and what arguments they have put forward, but, roughly speaking, on what picture of the mind emerges from the work of scientists.

Of course, there is no distinct group of scientists investigating the problem of normativity as in the case, for example, of neurologists studying the brain. It should be noted, however, that normativity manifests itself first and foremost in the domains of human activity or practices carried out by people. Manifestations of different forms of normativity (described earlier under the categories of the normative field) occur in various areas of human life (from social interactions to the processes of upbringing, learning, etc. to knowledge-generating practices, designing everyday objects and legislative processes). From this perspective, the analysis of normativity becomes the analysis of the different manifestations of normativity. At the same time, this perspective offers a language and an adequate set of tools to researchers. It also characterises the naturalism - anti-naturalism dispute not an objective dispute, but as an element in a conceptual framework or a modern way of thinking about normativity. The bottom-up approach, which must always be related to the top-down approach, is focused on describing and explaining the actual normative mechanisms in human actions. ${ }^{32}$ This raises doubts as to whether by investigating normativity we are concerned with normativity par excellence, or rather with existing types of normativity. Current discussions of the problem of normativity seem to favour the latter

of Science 67(2000), 1-25; P. Ylikoski, Social Mechanism, in International Encyclopedia of the Social \& Behavioral Sciences, 2nd edition, Vol. 22, Elsevier, 415-420. DOI: 10.1016/ B978-0-08-097086-8.03194-9.

32 It is not possible to abandon the top-down approach and it would also be highly undesirable. However, in line with the view expounded here it should be mapped out or constrained by the bottom-up approach. 
alternative. ${ }^{33}$ Hence, we should not think about a single normativity; rather, we should concentrate on different types of constructs, mechanisms and, eventually, normative practices. ${ }^{34}$

We should stress that there are different (perhaps mutually irreducible) types or manifestations of normativity (assuming that normativity par excellence exists), as well as that contemporary philosophy and science offer many different methods of studying and describing them. Perhaps the present task facing philosophy in this area is to integrate these different approaches and try to answer the question of the nature of normativity.

\section{$* * *$}

To an extent, the present selection of articles reflects current tendencies in normativity research. By 'tendencies' I mean the multitude of different accounts and a pluralistic way of thinking about normativity that does not aspire to a unique and special description or explanation. The authors discuss individual sections of the normative field, avoiding holistic accounts. Is such a minimalism in research a weakness? Quite the contrary. It reveals the extent of self-knowledge with which the authors approach and understand the specificity and uniqueness of this particular research topic. As mentioned before, this is an important aspect of contemporary philosophical reflection.

The collection is entitled Philosophy of Normativity. This should not be taken to indicate a new, separate philosophical discipline with its own language and tools, contained to a certain extent within the framework of a theoretical system. Rather, the title refers

33 I leave open the metaphysical question of whether normativity par excellence exists. See footnote 28 .

34 This belief is strictly related to the demand for interdisciplinary studies of normative phenomena. Some researchers stress the need to go beyond purely philosophical analysis and towards projects carried out by researchers representing different theoretical approaches. 
to a research tradition focused on the subject of normativity. Although this area of philosophical investigation is comparatively new, it is of primary importance. Even a superficial analysis of current debates makes it clear that normativity is a concept that requires researchers to take a position and explain it in some way, even if the explanation is only tentative. In every area of knowledge, research practice assumes an intuitive separation of the typical from the atypical; the norm from the exception; what is defined as correct from what is defined as incorrect or pathological. The aim of the research into normativity is also to offer a conceptual explanation of these intuitions.

In the opening paper 'Ought', Ownership and Agentive Ought. Remarks on the semantic meaning of 'indexed ought', Joanna Klimczyk asks whether a logical interpretation of "ought" in terms of an indexed ought has significant consequences for the proper interpretation of „ought” sentences with agentive content, i.e. telling the agent what she ought to do. In her considerations she refers to John Broome's recent discussion of Bernard Williams's paper Ought and Moral Obligation. Although Williams's focus was on moral ought, if we assume that a moral ought is naturally interpreted in terms of a personal requirement, as a practical ought typically is, then Williams's discussion becomes relevant to Broome's analysis of agentive ought. In his paper Williams claims that an ought, construed as issuing personal requirements to agents, is to be understood as an ordinary "ought" - namely, as a propositional operator that is not indexed to a person. Broome disagrees. Klimczyk accepts that Broome might be right, but contends that his arguments do not show this. Klimczyk holds that indexing ought to an agent does matter semantically once we propose a plausible substantive interpretation of an ,indexed ought". She claims that Broome's indexation in terms of ownership is seriously defective, and proposes her own account instead.

Andrzej Waleszczyński's Efekt Knobe'a z perspektywy etyki tomistycznej. Problem porzadków i kompetencji normatywnych dovetails with the discussion of a phenomenon first described by Joshua Knobe, 
and consisting in an asymmetrical attribution of intentionality to actions based on their side effects. Waleszczyński's contribution to this debate shows that there are different normative systems and two aspects of cognition: „informing about a moral evaluation” of a given object and ,informing about facts" (empirical facts) related to human actions. According to Waleszczyński, normative systems (or cognitive systems) have become mixed in the discussion so far. By analysing these systems, we can explain the Knobe Effect in a novel way and demonstrate the existence of the so-called normative competences.

In Two Arguments Supporting the Thesis of the Predictive Nature of Reasons for Action, Michał Piekarski presents a view whereby there are situations in which the reasons in favour of performing an action are predictions about future states of affairs and the consequences of the actions performed. The author advances two arguments in favour of this thesis. One is based on analyses of the Knobe Effect relating to the asymmetry between attributing intentionality and attributing responsibility for actions; the other argument on the cognitive science theory of predictive processing. Adopting these arguments, Piekarski partially challenges the thesis according to which folk psychology categories have explanatory value for human actions.

Piotr Kozak's Emocje epistemiczne i normatywnośc albo o tym jak pokochać teorię znaczenia concerns the normative nature of epistemic emotions such as the feeling of correctness or incorrectness. The author claims that to explain these phenomena we must take account of their non-discursive and non-representational nature. $\mathrm{He}$ also argues that we should acknowledge the constitutive role of such emotions as conditions that make the meaning and application of concepts possible.

In Normatywnośc usytuowana. Ujęcie ekologiczne, Witold Wachowski wonders whether and how we can talk about norms as affordances. When answering this question, we should take account of existing theories of affordances. Based on their critical analysis, the author 
concludes that normativity is cognitively located in the human environment understood as a physical, biological and cultural complex. At the same time, he underlines that it is difficult to equate norms with affordances as traditionally understood. Therefore, norms should be related to cultural affordances as well as their design and modifications.

The article $O$ perwnym dwugtosie w szkole lwowsko-warszawskiej. Normatywnośc między etologiq a etykq empirycznq by Władysław Kmiecikowski discusses the problem of normativity as approached by the Lwów-Warsaw School. Kmiecikowski's reflections are based on the analysis of the views of Maria Ossowska and Tadeusz Czeżowski, two philosophers who are representative of the School. The author shows that Ossowska's ethology and Czeżowski's empirical ethics pave the way for advanced moral analyses of normativity. He also outlines interesting meta-ethical perspectives that help demonstrate the bipolar nature of ethical discourse in science. Lastly, he substantiates the view that ethics pursued in the empirical paradigm may improve the methodological quality of discourse, as well as ethologically broaden our knowledge of the actual social and psychological contexts of morality. Furthermore, it may also help vindicate the scientific status of ethical statements and demonstrate the paradigmatic importance of moral normativity.

In Jaka normatywnośc po „śmierci Boga”? Etyczne implikacje myśli stabej, Andrzej Kobyliński analyses the concept of normativity in the philosophy of Gianni Vattimo. Vattimo's weak thought is a theory proclaiming the end of metaphysics and challenging the notion of the Cartesian subject. Adopting this concept should lead us to acknowledge a weak form of normativity, i.e. a normativity that does not claim to be universally applicable. Kobyliński demonstrates that normativity in this sense is justified on the grounds of cultural heritage, consent and social contract, thus breaking with the universalist thinking about ethical obligations and moral norms. 
In her article entitled Performatywnośc jezzyka a powinnośc moralna, Karolina Rozmarynowska analyses the performative function of language. She reflects upon the way in which performative language functions in terms of promises creating subjective obligations. She draws attention to the fact that some linguistic expressions create specific obligations. The latter are not based on expression semantics, but on eponymous performativity understood as the „ability to change reality". Rozmarynowska underlines, however, that performative analysis alone does not explain the sense of the promise itself or its significance to people. ${ }^{35}$

\section{REFERENCES}

Audi R., Ethical Naturalism, in: The Oxford Handbook of Ethical Theory, ed. D. Copp, Oxford University Press, Oxford 2006, 91-121.

Audi R., Natura normatywności oraz projekt naturalizacji pojęć normatywnych, in: $W$ świecie powinności, eds. B. Brożek, M. Hohol, Ł. Kurek, J. Stelmach, Copernicus Center Press, Kraków 2013, 37-78.

Barandiaran X., Egbert M., Quantifying Normative Behaviour and Precariousness in Adaptive Agency, in: Proceedings of the 11th European Conference on Artificial Life, eds. T. Lenaerts, M. Giacobini et al., Presented at the ECAL, MIT Press 2011, 210-218.

Barandiaran X., Egbert M., Norm-Establishing and Norm-Following in Autonomous Agency, Artificial Life Journal 20(2014), 5-28.

Barandiaran X., Di Paolo E., Rohde M., Defining Agency. individuality, normativity, asymmetry and spatio-temporality in action, Journal of Adaptive Behavior 17(2009)5, 367-386, DOI: 10.1177/1059712309343819.

Bicchieri C., The Grammar of Society, Cambridge University Press, New York 2006. Bicchieri C., Muldoon R, Social Norms, in: The Stanford Encyclopedia of Philosophy (Spring 2014 Edition), ed. E. N. Zalta, URL = https://plato.stanford.edu/ archives/spr2014/entries/social-norms/ (access 02.01.2018).

Bickhard M., Process and Emergence: Normative Function and Representation, in: Process Theories. Crossdisciplinary studies in dynamic categories, ed. J. Seibt, Springer, Dordrecht 2003, 121-155. DOI: 10.1007/978-94-007-1044-3_6.

35 The articles by Władysław Kmiecikowski, Andrzej Kobyliński and Karolina Rozmarynowska will be published in the next issue of Studia Philosophiae Christiane. 
Bickhard M. The interactivist model, Synthese 3(2009)166, 547-591. DOI: 10.1007/ s11229-008-9375-x.

Bickhard M., Christensen W., The Process Dynamics of Normative Function, The Monist 85(2002)1, 3-28.

Boghossian P., The Rule-Following Considerations, Mind 98(1989), 507-549.

Boghossian P., The Normativity of Content, Philosophical Issues 13(2003), 31-45. Brandom R.B., Making It Explicit: Reasoning, Representing, and Discursive Commitment, Harvard University Press, Cambridge MA 1994.

Brandom R.B., Articulating Reasons, Harvard University Press, Cambridge MA 2000.

Broome J., Is rationality normative?, Disputatio 23(2007), 161-178.

Brożek B., Normatywność prawa, Wolters Kluwer Polska - LEX, Kraków 2012.

Brożek B., Pojęcie normatywności, in: A. Brożek, B. Brożek, J. Stelmach, Fenomen normatywności, Copernicus Center Press, Kraków 2013, 19-44.

Churchland P.S., Braintrust, Princeton University Press, Princeton 2011.

Copp D., Moral naturalism and Three Grades of Normativity, in: Normativity and Naturalism, ed. P. Schaber, Ontos Verlag, Frankfurt am Main 2004, 7-45.

Craver C.F., When mechanistic models explain, Synthese 153(2006)3, 355-376, DOI: 10.1007/s11229-006-9097-x.

Darden L., Reasoning in Biological Discoveries, Cambridge University Press, Cambridge MA 2006.

Davies P.S., Norms of Nature. Naturalism and the Nature of Functions, MIT Press, Cambridge MA 2001.

De Waal F., Primates and Philosophers: How Morality Evolved, Princeton University Press, New Jersey 2006.

De Waal, F., Natural Normativity: The 'Is' and 'Ought' of Animal Behavior, Behaviour 151(2014), 185-204.

Dretske F., Explaining Behavior: Reasons in a World of Causes, MIT Press, Cambridge MA 1988.

Duchliński P., Normatywność - jej źródta i sposoby badania. Analiza metateoretyczna, w: Duchliński P., Kobyliński A., Moń R., Podrez W., O normatywności w etyce, Wydawnictwo Wam, Kraków 2015, 16-62.

Friston K.J., Free Energy Principle for Biological Systems, Entropy 14(2012), 2100-2121.

Friston K.J., Stephan K.E., Free-energy and the brain, Synthese 159(2007), 417-458.

Gibbard A., Meaning and Normativity, Philosophical Issues 5(1994), 95-115.

Godfrey-Smith P., A Modern History Theory of Functions, Noûs 28 (1994), 344-362. 
Haidt J., The Emotional Dog and Its Rational Tail, Psychological Review 108(2001)4, 814-834.

Hartmann N., Ethik, De Gruyter, Berlin 1926.

Heller M, Przeciw fundacjonizmowi, in: M. Heller, Filozofia i wszechświat, Universitas, Kraków 2006, 82-104.

Henderson D., Norms, in: The Oxford Handbook of Philosophy of Social Science, ed. H. Kingcaid, Oxford University Press, Oxford 2017, 409-435.

Hohol M., The Normativity of Mathematics. A Neurocognitive Approach, in: The Many Faces of Normativity, eds. J. Stelmach, B. Brożek, M. Hohol, Copernicus Center Press, Kraków 2012, 191-222.

Hutchins E., Cognition in the wild, MIT Press, Cambridge MA 1995.

Hutchins E., Cognitive Ecology, Topics in Cognitive Science 2(2010)4, 705-715.

Ingarden R., Wyktady z etyki, PWN, Warszawa 1989.

Kalinowski J., Teoria poznania praktycznego, WN KUL, Lublin 1960.

Kelsen H., General Theory of Law and State, Harvard University Press, Cambridge MA 1945.

Korsgard Ch., The Sources of Normativity, Cambridge University Press, New York 1996.

Kripke S., Wittgenstein on Rules and Private Language, Harvard University Press, Cambridge MA 1982.

Machamer P.K., Darden L., Craver C.F., Thinking about Mechanisms, Philosophy of Science 67(2000), 1-25.

Millikan R.G., Language, thought, and other biological categories: new foundations for realism, The MIT Press, Cambridge MA 1984.

Millikan R.G., Biofunctions, in: Functions. New Essays in the Philosophy of Psychology and Biology, eds. A. Ariew, R. Cummins, M. Perlaman, Oxford University Press, Oxford 2002.

Moń R., Warto czy należy? Studium na temat istoty i źródet normatywności, Wydawnictwo Naukowe UKSW, Warszawa 2011.

Piekarski M., Frans de Waal ifilozofowie, Avant. Trends in Interdisciplinary Studies 3(2015)VI, 138-147.

Piekarski M., Od typiki doświadczenia do normatywnej antycypacji. Przyczynek do fenomenologii normatywności, Filo-Sofija 33(2016)2, 71-86.

Piekarski M., Two Arguments Supporting the Thesis about the Predictive Nature of Reasons for Action, present volume, 93-119.

Piekarski M., Wachowski W., Artifacts as Social Things: Design-Based Approach to Normativity, under review. 
Scheler M., Der Formalismus in der Ethik und die materiale Wertetbik: Neuer Versuch der Grundlegung eines ethischen Personalismus, Felix Meiner Verlag, Hamburg 2014.

Wachowski W., Normatywność usytuowana. Ujęcie ekologiczne, present volume, 143-165.

Tomasello M., A Natural History of Human Thinking, Harvard University Press, Cambridge MA 2014.

Waleszczyński A., Efekt Knobe’a zperspektywy etyki tomistycznej. Problem porzadków $i$ kompetencji normatywnych, present volume, 65-92.

Whiting D., What is the Normativity of Meaning?, Inquiry 59(2013) 3, 219-238.

Ylikoski P., Social Mechanism, in International Encyclopedia of the Social E Behavioral Sciences, 2nd edition, Vol. 22, Elsevier, 415-420. DOI: 10.1016/ B978-0-08-097086-8.03194-9.

This article was supported by National Science Centre funds granted under decision No. DEC-2017/01/X/HS1/00165. I wish to thank Piotr Kozak, Witold Wachowski and Andrzej Waleszczyński for inspiring comments and discussions that helped me write this article.

Michat PIEKARSKI

m.piekarski@uksw.edu.pl

Cardinal Stefan Wyszynski University in Warsaw, Institute of Philosophy

Wóycickiego 1/3, 01-938 Warsaw, Poland

DOI:10.21697/spch.2018.54.1.11 